\title{
Role of Cerebrospinal Fluid - Adenosine Deaminase Level in Early diagnosis of Various Etiologies of Meningitis in children
}

\author{
Malla K, ${ }^{1^{*}}$ Rao KS, ${ }^{1}$ Malla $\mathrm{T}^{1}$ Vedamony $J,{ }^{2}$ Ghimire $\mathrm{P}^{3}$ \\ ${ }^{1}$ Department of paediatrics, Manipal College of Medical Sciences, Pokhara, Nepal, ${ }^{2}$ Clinical data centre operator, \\ Auckland, ${ }^{3}$ Medical Officer, Emergency Department, Manipal Teaching Hospital, Pokhara, Nepal
}

\section{*Corresponding Author: \\ Dr. Kalpana Malla \\ Associate Professor; Department of Paediatrics \\ Manipal Teaching Hospital, Pokhara, Nepal \\ Email: kalpana_malla@hotmail.com}

\section{Citation}

Malla K, Rao KS, Malla T, Vedamony J, Ghimire P. Role of Cerebrospinal Fluid-Adenosine Deaminase Level in Early diagnosis of Various Etiologies of Meningitis in children. Nepal Journal of Medical sciences 2012;1(2):97-102.

\begin{abstract}
Background: Determination of cerebrospinal fluid-adenosine deaminase (CSF-ADA) activity is a reliable means to differentiate tubercular from non- tubercular meningitis. This study was carried out to see the range with mean CSF-ADA levels in meningitis of various etiologies and to see if early diagnosis is possible based on these levels.
\end{abstract}

Methods: A prospective study of 140 children admitted in Manipal Teaching Hospital, from July 2009 - June 2011. Diagnosis was established by clinical findings and relevant investigations and patients were divided in different groups as pyogenic meningitis (PM), partially treated meningitis (PPM), tubercular meningitis (TBM), viral meningitis (VM) and controls. CSF-ADA estimation was done by using spectrophotometer.

Results: Out of total 140 patients, 103 were cases of meningitis and 37 were controls. There were 32 cases of PM, 27 cases of PPM, 34 cases of $\mathrm{VM}$ and 10 cases of TBM. The mean \pm SD with range of CSF-ADA was respectively $48 \pm 20.37 \mathrm{IU} / \mathrm{L}(20-70 \mathrm{IU} / \mathrm{L}), 14.57 \pm 6.48 \mathrm{IU} / \mathrm{L}(2-28 \mathrm{IU} / \mathrm{L})$, $6.40 \pm 2.17 \mathrm{IU} / \mathrm{L}(3-9 \mathrm{IU} / \mathrm{L}), 8.29 \pm 10 \mathrm{IU} / \mathrm{L}(3-11 \mathrm{IU} / \mathrm{L})$ and $5.27 \pm 2.69$ IU/L (2-7 IU/L) in TBM, PM, PPM, VM and controls and the value was highest in TBM. The specificity, sensitivity, positive predictive value and negative predictive value of CSF-ADA for TBM were 94.6\%, $100 \%$, $83.3 \%$ and $100 \%$.

Conclusion: Estimation of ADA activity in CSF can be of great value in early diagnosis of tubercular meningitis. Furthermore it is a simple, reliable, relatively inexpensive test with easy procedure.

Keywords: Cerebrospinal fluid; adenosine deaminase; tubercular meningitits

\section{Background:}

The outcome of meningitis specially the Tubercular meningitis (TBM) is influenced by the stage of disease at the start of treatment. Hence the management of meningitis is clearly influenced by the development of an accurate, reliable and rapid diagnostic test, particularly in a set up like ours with poor resources. Since the clinical features and cerebrospinal fluid (CSF) cytology, biochemistry shows considerable overlap in different forms of meningitis, there is a need of other modalities to support an etiological diagnosis of meningitis. 
Considering that both humoral and cell-mediated immunity play an important role in Tubercular meningitis (TBM) infection, it has been suggested that adenosine deaminase (ADA) activity in CSF may help differentiate TBM from non-Tubercular meningitis. ${ }^{1}$ The measurement of ADA was initiated by Giusti in 1981 and applied extensively in clinical practice. $^{2}$ With this in view this study was conducted to assess the role of CSF-ADA levels as a sensitive, accurate, rapid, affordable and early diagnostic tool in confirming different etiologies of meningitis.

\section{Methods:}

A prospective,casecontrolledstudy was conducted in Manipal Teaching Hospital from July 2009 to June 2011 in a total of 140 children aged between 1 month to 15 years ( 103 case of meningitis and 37 age and sex matched controls), admitted in the Pediatric ward. Ethical approval was obtained from the Ethics committee of the hospital and informed consent from parents was also obtained.

The diagnosis of meningitis was made on the basis of clinical features and CSF analysis. Then whole population was divided into groups based on the CSF cytochemistry: ${ }^{3}$

Group 1 - Pyogenic meningitis (PM) - CSF Gram's staining /or culture positive for bacteria. In cases of negative CSF Gram's staining and culture the CSF neutrophilicpleocytosis, i.e., cell count $100-10,000 / \mathrm{mm}^{3}$ with polymorphonuclear neutrophils (PMNs) representing $>50 \%$, the CSF glucose $<2 / 3^{\text {rd }}$ of blood sugar level and CSF protein $100-500 \mathrm{mg} / \mathrm{dl}$ was considered.

Group2 - Partially treated meningitis (PPM) - who already received antibiotic before CSF analysis and CSF leukocyte count 5-10,000 with PMNs or lymphocytes predominating, protein $100-500 \mathrm{mg} / \mathrm{dl}$, sugar $>2 / 3^{\text {rd }}$ of blood sugar level.

Group 3-TBM- History of contact with Sputum positive TB case, Clinico- radiological findings consistent with TB, and positive reaction ( $>20 \mathrm{~mm}$ indurations) to 5 tuberculin unit (TU) purified protein derivative (PPD) and CSF pleocytosis of $10-500 / \mathrm{mm} 3$ with predominant lymphocytes and high CSF protein 100-3000 mg/dl or CSF culture and/or ZiehlNeelsen staining have revealed Acid Fast Bacilli.

Group 4 - Viral meningitis (VM) - CSF pleocytosis of $<100$ $/ \mathrm{mm} 3$ with lymphocyte predominance, protein $50-200 \mathrm{mg} /$ $\mathrm{dl}$ and glucose $>2 / 3^{\text {rd }}$ of blood sugar level.

Group 5 controls - fever with convulsions having normal CSF findings.
The exclusion criteria were fungal meningitis, concomitant illness such as HIV/on immunosuppressive therapy. Conditions which can contribute in elevation of CSFADA activity in body fluids like - typhoid fever, infectious mononucleosis, viral hepatitis, rheumatologic diseases intracranial tumors and lymphoproliferative disorders were also excluded from the study. ${ }^{4}$

CSF-ADA estimations was done by method of Giusti, ${ }^{2}$ using spectrophotometer at optimum wave length of 570$630 \mathrm{~nm}$. A cutoff reference range of $>10 \mathrm{IU} / \mathrm{L}$ CSF-ADA was considered positive. Other laboratory investigations included complete blood count, blood sugar and blood culture. Data was analyzed by Epi info software version 3.5.2.

\section{Results:}

Out of total 140 patients, 103 were cases of meningitis and 37 were controls whose diagnosis was other than meningitis such as mental retardation, epilepsy, febrile convulsions. There were 32 cases of PM, 27 cases of PPM, 34 cases of $\mathrm{VM}$ and 10 cases of TBM.

Meningitis was noted highest in age group 5-10 years with bacterial meningitis predominating inall age groups. TBM was noted more in age group of $>10-15 y$ rs (Table 1 ).

Table 1: Distribution of various types of meningitis in different age groups

\begin{tabular}{cccccc}
\hline $\begin{array}{c}\text { Age } \\
\text { groups }\end{array}$ & $\begin{array}{c}\text { Pyogenic } \\
\text { meningitis }\end{array}$ & $\begin{array}{c}\text { Partially } \\
\text { treated } \\
\text { meningitis }\end{array}$ & $\begin{array}{c}\text { Viral } \\
\text { meningitis }\end{array}$ & $\begin{array}{c}\text { Tubercular } \\
\text { meningitis }\end{array}$ & Controls \\
\hline$<2$ yrs & 8 & 5 & 4 & 0 & 18 \\
\hline $2-5$ yrs & 5 & 4 & 3 & 1 & 7 \\
& 11 & 13 & 17 & 2 & 11 \\
$5-10$ yrs & 11 & & & & \\
$10-15$ yrs & 8 & 5 & 10 & 7 & 1 \\
\hline
\end{tabular}

The common clinical presentations of meningitis were: fever, vomiting, lethargy, headache, convulsion, neck rigidity, and positive Kernig's sign and Bruzniski sign. Less common presentations were: Photophobia and Loss of consciousness. All the clinical features were noted more in TBM (Table 2). 
Table 2: Clinical presentation in different groups of meningitis and controls

\begin{tabular}{|c|c|c|c|c|c|}
\hline $\begin{array}{l}\text { Clinical } \\
\text { Features }\end{array}$ & $\begin{array}{l}\text { Pyogenic } \\
\text { meningitis } \\
(\mathrm{N}=32)\end{array}$ & $\begin{array}{l}\text { Partially } \\
\text { treated } \\
\text { meningitis } \\
(\mathrm{N}=27)\end{array}$ & $\begin{array}{c}\text { Viral } \\
\text { meningitis } \\
(\mathrm{N}=34)\end{array}$ & $\begin{array}{l}\text { Tubercular } \\
\text { meningitis } \\
(\mathrm{N}=10)\end{array}$ & $\begin{array}{c}\text { Controls } \\
(\mathrm{N}=37)\end{array}$ \\
\hline Vomiting & $29(91 \%)$ & $21(78 \%)$ & $29(85 \%)$ & $9(90 \%)$ & $17(46 \%)$ \\
\hline Headache & $22(69 \%)$ & $18(67 \%)$ & $23(68 \%)$ & $8(80 \%)$ & $11(30 \%)$ \\
\hline $\begin{array}{c}\text { Loss of } \\
\text { consciousness }\end{array}$ & $11(34 \%)$ & $1(4 \%)$ & $3(9 \%)$ & $5(50 \%)$ & $1(3 \%)$ \\
\hline Convulsion & $21(66 \%)$ & $15(56 \%)$ & $17(50 \%)$ & $5(50 \%)$ & $34(92 \%)$ \\
\hline Lethargic & $25(78 \%)$ & $16(59 \%)$ & $21(62 \%)$ & $9(90 \%)$ & $18(49 \%)$ \\
\hline Fever & $32(100 \%)$ & $27(100 \%)$ & $34(100 \%)$ & $10(100 \%)$ & $36(97 \%)$ \\
\hline Photophobia & $6(19 \%)$ & $5(19 \%)$ & $1(3 \%)$ & $2(20 \%)$ & $1(3 \%)$ \\
\hline Neck rigidity & $25(78 \%)$ & $18(67 \%)$ & $24(71 \%)$ & $9(90 \%)$ & $5(13 \%)$ \\
\hline Kernig's sign & $17(53 \%)$ & $12(44 \%)$ & $12(35 \%)$ & $8(80 \%)$ & $2(5 \%)$ \\
\hline Brudzniski sign & $16(50 \%)$ & $12(44 \%)$ & $9(26 \%)$ & $9(90 \%)$ & $1(3 \%)$ \\
\hline Others & $17(53 \%)$ & $6(22 \%)$ & $18(53 \%)$ & $8(80 \%)$ & $23(62 \%)$ \\
\hline
\end{tabular}

Mycobacterium tuberculi could not be isolated in any of the 10 TBM cases. Organisms were isolated in blood culture in 4 out of 32 cases (Enterococcus -2, Pseudomonas -1, E.coli-1) and in CSF culture in 8 out of 32 cases of PM (E.coli -2, Enterococcus-1, Staphylococcus aureus-2, Pseudomonas-1, Streptococcus pneumoniae- 2).

The CSF total count and neutrophil count was highest and sugar lowest in PM group (Table 3).

Table 3:Blood and CSF laboratory parameters in various types of meningitis

\begin{tabular}{cccccc}
\hline Variables & $\begin{array}{c}\text { Pyogenic } \\
\text { meningitis } \\
\text { Mean } \pm \text { SD }\end{array}$ & $\begin{array}{c}\text { Partially } \\
\text { treated } \\
\text { meningitis } \\
\text { Mean } \pm \text { SD }\end{array}$ & $\begin{array}{c}\text { Tubercular } \\
\text { meningitis }\end{array}$ & $\begin{array}{c}\text { Viral } \\
\text { meningitis }\end{array}$ & $\begin{array}{c}\text { Control } \\
\text { Mean } \pm \text { SD }\end{array}$ \\
\hline Blood & & & & & \\
Total count & $12896 \pm 5959$ & $12922 \pm 6068$ & $12920 \pm 3840$ & $12002 \pm 4204$ & $14440 \pm 7596$ \\
Neutrophil & $84.71 \pm 9.23$ & $79.55 \pm 11.02$ & $78.00 \pm 13.66$ & $75.70 \pm 17.19$ & $75.24 \pm 16.37$ \\
Lymphocytes & $15.81 \pm 12.26$ & $39.62 \pm 26.82$ & $90.60 \pm 8.11$ & $86.23 \pm 18.75$ & $5.40 \pm 22.92$ \\
RBS & $106 \pm 29.84$ & $98 \pm 31.81$ & $98 \pm 29.85$ & $88 \pm 21.36$ & $100 \pm 30.72$ \\
CSF & & & & & \\
Total count & $903.28 \pm 1419$ & $231.07 \pm 303$ & $158.40 \pm 133$ & $118.94 \pm 246$ & $0.10 \pm 0.45$ \\
Neutrophil & $84.18 \pm 12.26$ & $60.37 \pm 26.82$ & $8.90 \pm 8.22$ & $10.88 \pm 11.57$ & $0.00 \pm 0.000$ \\
Lymphocytes & $15.81 \pm 12.26$ & $39.62 \pm 26.82$ & $90.60 \pm 8.11$ & $86.23 \pm 18.75$ & $5.40 \pm 22.92$ \\
Sugar & $29.15 \pm 15.11$ & $47.44 \pm 20.62$ & $40.30 \pm 13.69$ & $55.00 \pm 16.70$ & $65.48 \pm 16.75$ \\
Protein & $46.28 \pm 32.89$ & $43.85 \pm 51.89$ & $256.90 \pm 203$ & $30.05 \pm 19.40$ & $22.21 \pm 28.80$ \\
ADA & $14.57 \pm 6.48$ & $6.40 \pm 2.17$ & $48.00 \pm 20.37$ & $8.29 \pm 10.00$ & $5.27 \pm 2.69$ \\
\hline
\end{tabular}

CSF Lymphocyte and Protein was highest in TBM. The ranges of CSF-ADA with mean $\pm \mathrm{SD}$ of different groups are shown in Table 4.

Table 4:CSF-ADA in different groups

\begin{tabular}{lccccc}
\hline \multicolumn{1}{c}{ Study groups } & $\begin{array}{c}\text { Range } \\
\text { of ADA } \\
\text { level } \\
\text { (IU/L) }\end{array}$ & $\begin{array}{c}\text { CSF-ADA } \\
\text { Positive }\end{array}$ & \multicolumn{2}{c}{$\begin{array}{c}\text { CSF -ADA } \\
\text { Negative }\end{array}$} \\
\hline Pyogenic meningitis & $2-28$ & 22 & $69 \%$ & 10 & $32 \%$ \\
Partially treated meningitis & $3-10$ & 0 & $0 \%$ & 27 & $100 \%$ \\
Viral meningitis & $3-11$ & 6 & $18 \%$ & 28 & $82 \%$ \\
Tubercular meningitis & $20-70$ & 10 & $100 \%$ & 0 & $0 \%$ \\
Control & $2-7$ & 1 & $3 \%$ & 36 & $97 \%$ \\
\hline
\end{tabular}

The CSF-ADA activity was found to be increased in the order $\mathrm{TBM}>\mathrm{PM}>\mathrm{VM}>\mathrm{PPM}>$ control. All 10 cases of TBM patients had CSF-ADA above the cutoff value of $>$ $10 \mathrm{IU} / \mathrm{L}$. All of 27 PPM patients had CSF-ADA $<10 \mathrm{IU} / \mathrm{L}$. Twenty two out of thirty two PM patients, 6/34 VM cases and 1/37 control had CSF-ADA level > $10 \mathrm{IU} / \mathrm{L}$ (Table 4).

Table 5 reveals the sensitivity, specificity, positive and negative predictive values of CSF-ADA activity.

Table 5:CSF-ADA efficacy with a cut off value $>10 \mathrm{IU} / \mathrm{L}$

\begin{tabular}{|c|c|c|c|c|}
\hline Types of meningitis & Sensitivity & Specificity & $\begin{array}{c}\text { Positive } \\
\text { predictive } \\
\text { Value }\end{array}$ & $\begin{array}{c}\text { Negative } \\
\text { predictive } \\
\text { value }\end{array}$ \\
\hline $\begin{array}{l}\text { Pyogenic } \\
\text { meningitis }\end{array}$ & $68 \%$ & $77 \%$ & $57.1 \%$ & $84 \%$ \\
\hline $\begin{array}{l}\text { Partially treated } \\
\text { meningitis }\end{array}$ & $0 \%$ & $50 \%$ & $0 \%$ & $58.3 \%$ \\
\hline $\begin{array}{l}\text { Tubercular } \\
\text { meningitis }\end{array}$ & $100 \%$ & $94.5 \%$ & $83.3 \%$ & $100 \%$ \\
\hline Viral meningitis & $17.6 \%$ & $53.6 \%$ & $15.7 \%$ & $56.9 \%$ \\
\hline
\end{tabular}

\section{Discussion:}

Demonstration of Acid FastBacilli or isolation of bacteria in CSF culture is usually difficult and in most cases direct smear methods for TBM are often negative and culturing of Mycobacterium takes 4-6 weeks to show the growth ${ }^{5}$ and in bacterial meningitis when patient comes after a course of antibiotics, organisms are usually not isolated. CSF cytology, biochemistry is other means to confirm the etiology but again, the results may overlap. Furthermore the 
newer methods to diagnose TBM such as bacterial genomic amplifications by Polymerase Chain Reaction or other comparable methods are not available for widespread use in the developing countries.

Due to the difficulty in establishing the diagnosis of meningitis using clinical, radiological (magnetic resonance imaging or computed tomography), cytological, biochemical and even microbiological approaches, additional tests should be developed.

ADA has been considered as a marker of cell-mediated immunity and its activity has been observed in various infections including TBM. ${ }^{6}$ CSF-ADA estimation was reported to be useful in diagnosing TBM and to differentiate TBM from normal subject or patients with other neurological disorders. ${ }^{6} \mathrm{CSF}-\mathrm{ADA}$ estimation is also a useful method to differentiate TBM from aseptic meningitis. ${ }^{7}$ Other researchers have also reported the usefulness of CSF-ADA activity in the diagnosis of TBM. ${ }^{8}$ ADA is an enzyme that catalyses the deamination of adenosine, forming inosine in the process. ${ }^{9}$ ADA activity increases in cell mediated immune response during T-cell differentiation and proliferation.

Various studies have been conducted demonstrating CSFADA estimation as an enzymatic assay in diagnosis of TBM and it can differentiate TBM from normal subjects or other infectious meningitis. ${ }^{8,} 10,11$ In this study, PM was most common meningitis in all age group.

The common clinical presentations of meningitisobserved in this study were fever, vomiting, lethargy, headache, convulsion, neck rigidity, positive Kernig's sign and positive Bruzniski sign. Similar clinical presentations were also noted by other workers but with different frequencies. ${ }^{12}$

Mycobacterium could not be isolated in any of the TBM cases. The scenario differed from ours in the other two studies where $6 / 29$ and $2 / 19$ cases tested culture positive for mycobacterium. ${ }^{1,8}$ In $4 / 32$ patients of pyogenic meningitis, organisms were isolated in blood culture and in 8/32 in CSF culture, where Enterococcus and E.coli were the predominant organisms. Bacterial isolates in CSF in our study was less than that observed in other studies where it was $36 \%$, but the isolated organisms were similar to ours. ${ }^{13}$ Yet in another study, CSF culture was positive only in $16 \%$ cases. $^{14}$

The CSF total count $(903.28 \pm 1419.73)$ and neutrophil count $(84.18 \pm 12.26)$ in PM was highest. CSF Sugar was lowest $(29.15 \pm 15.11)$ in PM while the CSF Lymphocyte $(90.60 \pm 8.11)$ and Protein $(256.90 \pm 203.61)$ were highest in TBM. Similar findings were noted by other workers. ${ }^{14}$ These significant parameters may be additional supporting investigations to further differentiate different types of meningitis.

The range of ADA in this study was 20-70 IU/L in TBM with a mean of $48 \pm 20.37 \mathrm{IU} / \mathrm{L}$. Lower values than this study was observed in other studies $(39.44 \pm 41.46 \mathrm{IU} / \mathrm{L})^{16}$ and $(13.43 \pm 4.76 \mathrm{IU} / \mathrm{L}) .{ }^{17}$ This lower mean ADA activity in other studies may be due to the racial or difference in the method of estimation of ADA values and the difference in cutoff reference values in different labs. ${ }^{1}$ Another possible explanation for this difference may be due to difference in immunological reactivity to tubercular antigen in different individuals. ${ }^{1}$

The levels in PM, PPM, VM was also variable when compared with other studies. In our study the range of CSFADA was between 2-28 IU/L with mean $14.57 \pm 6.48 \mathrm{IU} / \mathrm{L}$ in PM. In another study a higher level $(34.20 \pm 40.81 \mathrm{IU} / \mathrm{L})$ was noted in pyogenic meningitis. ${ }^{16} \mathrm{~A}$ similar ranges between 3-9 IU/L with mean $6.40 \pm 2.17 \mathrm{IU} / \mathrm{L}$ in PPM and range of 3-11 IU/L with mean $8.29 \pm 10 \mathrm{IU} / \mathrm{L}$ was observed in VM. ${ }^{16}$ A similar value $(10.03 \pm 9.23)$ in viral meningitis was noted in another study. ${ }^{16}$

In our study, the control group CSF-ADA range was 2-7 IU/L with a mean $5.27 \pm 2.69 \mathrm{IU} / \mathrm{L}$. This was reported to be $2.58 \pm 2.90 \mathrm{IU} / \mathrm{L}$ by other workers. ${ }^{16}$ The mean ADA activity was $8.23 \pm 2.91 \mathrm{IU} / \mathrm{L}$ and $2.64 \pm 1.57 \mathrm{IU} / \mathrm{L}$ in $\mathrm{PM}$ and controls respectively in another study. ${ }^{17}$ The range and mean CSF-ADA level much lower than in our study was observed in yet another study ${ }^{12}$ where the range was 6.2-21.8 IU/L with a mean of $12.23 \mathrm{IU} / \mathrm{L}$ in TBM, a range of 1.6-5.6 IU/L with a mean of $4.37 \mathrm{IU} / \mathrm{L}$ inPM, a range of $1.11-8.3 \mathrm{IU} / \mathrm{L}$ with a mean of $3.32 \mathrm{IU} / \mathrm{L}$ in VM and a range of $0.33-2.8$ IU/L with a mean of 1.37 in controls. However the order of increaseof $\mathrm{CSF}-\mathrm{ADA}$ activity was the same as ours $\mathrm{TBM}>$ $\mathrm{PM}>\mathrm{VM}>$ control.

The sensitivity and specificity of CSF-ADA (with cutoff point of $10 \mathrm{IU} / \mathrm{L}$ ) was $100 \%$ and $94.5 \%$. The sensitivity for PPM patients was $0 \%$ and specificity was $50 \%$. Twenty two out of 32 PM patients and 6/34 VM cases had CSF ADA $>$ $10 \mathrm{IU} / \mathrm{L}$ while the rest had values $<10 \mathrm{IU} / \mathrm{L}$, hence the sensitivity and specificity was $68 \%$ and $77 \%$ for PM and $17.6 \%$ and $53.6 \%$ for VM.

At a cut off value of $10.5 \mathrm{IU} / \mathrm{L}$ the sensitivity of $80.95 \%$ and specificity of $85.71 \%$ for diagnosing TBM was reported by other authors. ${ }^{18}$ Yet in another study with a CSF-ADA cutoff value of $10 \mathrm{IU} / \mathrm{L}$, exhibited $94.73 \%$ sensitivity and $90.47 \%$ 
specificity in differentiating tubercular from non-tubercular meningitis. ${ }^{2}$ In another study, the sensitivity and specificity of ADA in CSF, at cut-off level of $10 \mathrm{IU} / \mathrm{L}$, showed $100 \%$ and $93.75 \%$ respectively, ${ }^{17}$ which was very similar to our study.

Other studies have shown sensitivity ranges of $44-100 \%$ and specificities of $75-99 \%$ for total ADA (by using 8 to $20 \mathrm{IU} / \mathrm{L}$ as cutoff value for diagnosis. ${ }^{11,19,20}$

Possible reasons for the varying levels of sensitivity and specificity in different studies maybe due to different disease profiles, time of presentation, age ranges as younger age group have lower ADA values. ${ }^{20}$

The predictive accuracy of a test provides a greater practical value. The positive predictive value for TBM was $83.3 \%$ and negative predictive value $100 \%$ in this study. For TBM, a $90 \%$ positive predictive value and a $95 \%$ negative predictive value was noted by other workers. ${ }^{2}$

This supports the role of CSF-ADA in TBM. The predictive values in this study were lower in PM (57.1\% and 84\%), PPM (0\% and 58.3\%) and VM (5.7\% and 56.9\%).

\section{Conclusion:}

This study demonstrates that ADA concentration in the CSF of meningitis patients, using a cut off value $10 \mathrm{U} / \mathrm{L}$, can be useful in differentiating tubercular meningitis from other types of meningitis. Furthermore, considering the diagnostic limitations of conventional CSF variables (proteins, glucose and cells) especially when Gram stain and culture are negative, the CSF-ADA can provide pertinent, rapid and reliable diagnostic information, especially in TBM, which is particularly appropriate for areas lacking adequate laboratory facilities.

Hence ADA estimation in CSF is simple, inexpensive, rapid, fairly specific method for making a diagnosis of different etiology of meningitis. For this reason ADA estimation inmeningitis, especially in TBM may find a place as a routine investigation.

\section{Acknowledgments:}

We thank Dr. Ganesh BK, Dr. Shankar Poudel, Dr. Prithuja Poudyal, Dr. Kiran Panthee for assisting in this study.

\section{Conflict of interest: none}

\section{References:}

1. Bharat KG, Anchit B, Bandyopadhyay D, et al. Adenosine DeaminaseLevels in CSF of Tuberculous
Meningitis Patients. J Clin Med Res 2010;2:220-4.

2. Giusti G. Adenosine deaminase. In: Bergmeyer H U, ed. Methods of enzymatic analysis. New York, NY, USA: Academic Press 1974:1092-6.

3. Prober CG, Dyner LL. Central nervous system infections. In: Kliegman RM, Stanton BF,St.gem JW, eds.Nelson Textbook of Pediatrics. 19 ${ }^{\text {th }} \mathrm{ed} .2012$. Philadelphia PA: W.B. Saunders; 2088.

4. Thwaites G, Chau TT, Mai NT, etal.Tuberculous meningitis. J Neurol Neurosurg Psychiatry 2000;68:289-99.

5. Kashyap RS, Kainthla RP, Mudaliar AV, et al. Cerebrospinal fluid adenosine deaminase activity: a complimentary tool in the early diagnosis of tuberculous meningitis. Cerebrospinal Fluid Res 2006;3:5.

6. Blake J, Berman P. The use of adenosine deaminase assays in the diagnosis of tuberculosis. S Afr Med J 1982;62:19-21.

7. Malan C, Donald PR, Golden M, et al. Adenosine deaminase levels in cerebrospinal fluid in the diagnosis oftuberculous meningitis. J Trop Med Hyg 1984;87:3340.

8. Prasad R, Kumar A, Khanna BK. CSF-ADA for diagnosis of TBM. Ind J Tub 1991;38:99-102.

9. Fox IH, Kelly WN. The role of adenosine deaminase and 2'deoxyadenosine in mammalian cells. Ann Rev Biochem 1978;47:655-86.

10. Acevedo L BM, Lagos ME. Usefulness of adenosine deaminase determination in Cerebrospinal fluid for the diagnosis of meningeal tuberculosis; 4 years experience at a public hospital. Rev Med Chill 1996;124:319-26.

11. Pettersson $T$, Klockars $M$, Weber TH. Diagnostic value of cerebrospinal fluid adenosine Deaminase determination. Scand J Infect Dis 1991;23:97-100.

12. Rajesh B, Purnima L, RS Gehlot. CSF - Adenosine Deaminase (ADA) Activity in Various Types of Meningitis. J Ind Aca Clin Mede 2001;4:286-7.

13. Tankhiwale SS, Jagtap PM, Khadse RK, et al. Bacteriological study of pyogenic meningitis with special reference to C-reactive protein. Indian J Med Microbiol 2001;19:159-60.

14. Singh N, Arora S, Kahlon PS. Cerebrospinal Fluid C-reactive protein in Meningitis. Indian 
Original Article | Malla $\mathrm{K}$ et al. CSF-ADA in early diagnosis of meningitis in children

Pediatrics 1995;32:687-8.

15. Abro AH, Abdou AS, Ali H, et al. Cerebrospinal fluid analysis - acute bacterial versus viral meningitis. Pak J Med Sci 2008;24:645-50.

16. Chotmongkol V, Teerajetgul Y, Yodwut C. Cerebrospinal fluid adenosine deaminase activity for the diagnosis of tuberculous meningitis in adults. Southeast Asian J Trop Med Public Health 2006;37:948-52.

17. Desai KJ, Malek SS, Shah NI, et al. Diagnostic Evaluation of Adenosine Deaminase (ADA) Test in the Early Diagnosis of Tuberculous Meningitis. Int J Med Public Health 2011;1:9-12.

18. Niazi AA, Narouie B, Moghtaderi A, et al. Comparison of cerebrospinal fluid adenosinedeaminase concentration of tuberculous and non-tuberculousmeningitis. JBUMS 2009;16: 54-60.

19. Eintracht S, Silber E, Sonnenberg P, et al. Analysis of adenosine deaminase isoenzyme-2 (ADA-2) In cerebrospinal fluid in the diagnosis of TB meningitis. $\mathrm{J}$ Neurol neurosurg psychiatry 2000;69:137-8.

20. Gambbir IS, Mehta M, Singh DS, et al. Evaluation of CSF-adenosine deaminase activity in tubercular meningitis. J Assoc physician India 1999;47:192-4.

21. Donald $\mathrm{P}$, Malan $\mathrm{C}$, van der Walt A, et al. The simultaneous determination of cerebrospinal fluid and plasma adenosine deaminase activity as a diagnostic aid in tuberculous meningitis. S Afr Med J 1986;69:505-7. 